\title{
KOMUNIKASI PEDAGANG PASAR TRADISIONAL (PEKAN) DI KEUDE BULOH BLANG ARA KECAMATAN KUTA MAKMUR
}

\author{
M taufik ${ }^{1)}$, Masriadi ${ }^{2)}$ Muhammad $\mathrm{Ali}^{3)}$, \\ ${ }^{1)}$ Program Studi Ilmu Komunikasi, UniversitasMalikussalehemail: \\ mtaufik13579@gmail.com
}

\begin{abstract}
ABSTRAK
Penelitian ini dengan judul komunikasi pedagang pasar tradisional (pekan) Di keude buloh blang ara Kecamatan. Adapun pendekatan penelitian yang digunakan adalah metode kualitatif dengan menggunakan instrumen observasi, wawancara dan dokumentasi sebagai teknik pengumpulan data. Informan dalam penelitian ini sebanyak 10 (sepuluh) orang yang dipilih dengan menggunakan teknik purposive sampling. Teori yang digunakan dalam penelitian ini adalah teori Integrated marketing communication (IMC). Hasil penelitian menunjukkan bahwa komunikasi pemasaran pedagang pasar pekan tradisional di Keude Buloh Blang Ara Kecamatan Kuta Makmur yaitu penjualan langsung melalui tatap muka dengan pelanggan maupun menggunakan aplikasi watshaap terutama untuk promosi penjualan, mengikat hubungan dengan pelanggan terutama pelanggan-pelanggan baru. Dalam hal ini, penjual berupaya untuk membantu atau membujuk calon pembeli untuk membeli produk yang ditawarkan. Komunikasi yang terjadi antara pedagang dengan pembeli, adalah dengan konsep tatap muka, dimulai oleh pedagang dengan menawarkan jualan secara langsung kepada pembeli.
\end{abstract}

Kata Kunci : Komunikasi, Pedagang,Tradisional.

\section{PENDAHULUAN}

Dalam dunia bisnis, komunikasi termasuk kedalam item terpenting dari segalanya walaupun seorang pengusaha memiliki itu yang hebat namun tidak akan berguna sebelum dipublikasikan lewat komunikasi sehingga dapat dipahami oleh orang lain tentang produk dan bisnis seseorang. Komunikasi yang sempurna, jika hal itu memang ada, muncul ketika suatu pemikiran atau sebuah ide tersampaikan sedemikian rupa sehingga gambaran mental yang didapat oleh sipenerima sama dengan yang digambarkan sipengirimnya.

Meskipun komunikasi dianggap penting dalam dunia bisnis, akan tetapi nilai-nilai komunikasi perlu diperhatikan begitu juga dengan nilai-nilai normatif juga sangat dibutuhkan, karena hal tersebut sangat berhubungan erat dengan atitude (etika) dalam berbisnis. Nilai-nilai normatif dalam berbinis menjadi tolak ukur pada suatu kesuksesan bisnisnya, apalagi pada daerah-daerah yang memiliki nilai syari'ahnya yang lebih tinggi seperti Aceh sudah banyak nilai-nilai agama dalam bisnis yang sudah dibudayakan.

Dalam pelaksanaan aktivitas bisnis di dalam masyarakat seperti halnya pedagang

Jurnal Jurnalisme Edisi, 1 Volume 10 April 2021 
pasar pekan tradisional. Keberadaan pedagang pasar pekan tradisional merupakan hal yang penting karena memainkan peran yang vital dalam dunia usaha dalam mendorong pertumbuhan ekonomi seseorang terutama bagi golongan menengah ke bawah. Secara umum pedagang pasar pekan tradisional menjajakan berbagai macam dagangan, mulai dari jajanan pasar, kuliner (makanan), barang-barang bekas seperti sepatu, perkakas, dan barangbarang lainnya yang dibutuhkan oleh masyarakat.

Proses perdagangan tersebut tentunya sangat berhubungan dengan pasar, baik itu pasar tradisional maupun pasar modern, seperti minimarket, supermarket dan lain-lain. Berbicara pasar tentunya kita akan berpikir tentang konsep pasar tradisional yang masih sangat lekat dengan kehidupan masyarakat Indonesia saat ini, khususnya pasar Keude Buloh Blang Ara dan sekitarnya. Pasar tradisional tentunya tidak lepas dari permasalahan sampah, kotor, becek, dan sebagainya. Namun pada kenyataanya konsep pasar tradisional tersebut masih sangat erat dengan kehidupan masyarakat kuta makmur tersebut.

Seiring perkembangan zaman dengan kecanggihan teknologi saat ini, keberadaan pasar tradisional tentunya sudah mulai terancam dengan adanya pasar modern dan pasar online. Ditambah lagi permasalahan bahwa keberadaan pasar tradisional yang kurang jaman untuk melakukan transaksi jual beli, dikarenakan kebanyakan tempat pasar tradisional terlihat kotor dan semerawut, kemudian juga seringkali kualitas barang serta perhitungan harga yang tidak sesuai dengan apa yang diharapkan oleh pembeli, menjadi beberapa indikator berkurangnya minat pembeli untuk datang melakukan transaksi di pasar tradisional tersebut. hal tersebut tentunya memberikan dampak kurang nyaman bagi masyarakat pembeli, serta masyarakat pada umumnya. Dengan adanya permasalahan tersebut, prospek berjualan berkaitan dengan pendapatan para pedagang tradisional di pasar Keude Buloh Blang Ara, pastinya akan berkurang, berdasarkan permasalahan tersebut.

Berdasarkan beberapa identifikasi permasalahan komunikasi yang ada pada pedagang tradisional Keude Buloh Blang Ara tersebut, maka peneliti mencoba untuk menelusuri bagaimana komunikasi yang dilakukan oleh pedagang pasar tradisional tersebut dalam menjual bahan dagangan mereka agar tetap laku dan dapat juga menambah pendapatan pedagang tradisional itu sendiri. Yang menjadi rumusan masalah dalam penelitian ini adalah bagaimana komunikasi pedagang tradisional dalam menjual bahan dagangan di pasar Keude Buloh Blang Ara Kecamatan Kuta Makmur.

Tujuan penelitian ini adalah untuk mengetahui bagaimana komunikasi pedagang tradisional dalam menjual bahan dagangan di pasar Keude Blang Ara Kecamatan Kuta

\section{Jurnal Jurnalisme Edisi, 1 Volume 10 April 2021}


Makmur. Diharapkan hasil penelitian ini dalam memberikan manfaat bagi perkembangan ilmu komunikasi, berkaitan dengan permasalahan komunikasi. Hasil penelitian ini, diharapkan dapat memberikan masukan bagi para pedagang khususnya pedagang tradisional dalam upaya menjual dagangannya.

\section{LANDASAN TEORI}

Menurut Penelitian Lengkey (2019) tentang "Komunikasi Pedagang Tradisional Dalam Menjual Bahan Dagangan di Pasar Tateli Kecamatan Mandolang”. Penelitian ini menggunakan metode deskriptif dengan pendekatan kualitatif. Hasil dari penelitian ini menunjukan bahwa pola komunikasi antara pedagang dan pembeli terjadi dalam bentuk komunikasi antarpersonal, disertai dengan pendekatan komunikasi persuasif serta terjadi dalam situasi dialog interaktif berjalan secara tatap muka. Saluran atau media komunikasi yang dominan dipakai oleh para pedagang pasar Tateli adalah menggunakan mulut dan kemampuan suara, dalam menyampaikan barang dagangannya. Proses komunikasi pedagang ketika melakukan interaksi dengan pembeli ataupun calon pembeli, selalu mengedepankan etika dan kesopanan dalam berbicara menawarkan barang dagangannya. Hambatan komunikasi yang terjadi pada saat berjualan dipasar tateli tersebut adalah ratarata pedagang pasar Tateli belum kuasai pemahaman bahasa internasional, khususnya bahasa Inggris serta bahasa lainnya. Hambatan lain secara fisik fasilitas sarana dan prasarana pasar Tateli masih kurang baik, khususnya dalam hal kenyamanan pembeli dan pedagang pada saat hujan, dan malam hari belum terlalu layak

Persamaan penelitian Lengkey (2019) dengan penelitian ini adalah sama-sama meneliti mengenai komunikasi pedagang tradisional dan menggunakan metode pendekatan kualitatif deskriptif. Sementara perbedaannya, pada penelitian Lengkey difokuskan pada pola komunikasi dalam menjual barang dagangannya di Pasar Tateli Kecamatan Mandolang. Sedangkan penelitian ini difokuskan pada komunikasi pemasaran pedagang pasar pekan tradisional di Keude Buloh Blang Ara Kecamatan Kuta Makmur Kendala-kendala yang dihadapi oleh pedagang.

\section{Teori Integerated Marketing Communication}

Menurut Shimp (2007:7) Integrated marketing communication adalah proses pengembangan dan implementasi berbagai bentuk program komunikasi persuasif kepada pelanggan dan calon pelanggan secara berkelanjutan. Proses ) integrated marketing communication berawal dari pelanggan atau calon pelanggan, kemudian berbalik pada

\section{Jurnal Jurnalisme Edisi, 1 Volume 10 April 2021}


perusahaan atau industri untuk menentukan dan mendefinisikan bentuk dan metode yang perlu dikembangkan bagi program komunikasi yang persuasif.

Menurut Shimp (2007:24) adapun ciri-ciri dari integrated marketing communication itu antara lain adalah:

1. Mempengaruhi Perilaku. Tujuan integrated marketing communication adalah untuk mempengaruhi perilaku khalayak sasarannya. Hal ini berarti komunikasi pemasaran harus

melakukan lebih dari sekedar mempengaruhi kesadaran merek atau "memperbaiki" perilaku konsumen terhadap merek. Sebaliknya kesuksesan integrated marketing communication membutuhkan usaha-usaha komunikasi yang diarahkan kepada peningkatan beberapa bentuk respon dari perilaku konsumen.

2. Berawal dari pelanggan dan calon pelanggan. Konsep prosesnya diawali dengan dari pelanggan atau calon pelanggan, kemudian berbalik pada komunikator merek untuk menentukan metode yang paling tepat dan efektif dalam mengembangkan program komunikasi persuasi.

3. Menggunakan seluruh bentuk kontak, artinya integrated marketing communication menggunakan seluruh bentuk komunikasi dan seluruh "kontak" yang menghubungkan merek atau perusahaan dengan pelanggan mereka, sebagai jalur penyampai pesan yang potensial.

4. Menciptakan sinergi. Dalam definisi integrated marketing communication terkandung kebutuhan akan sinergi (keseimbangan). Semua elemen komunikasi (iklan, tempat pembelian, promosi penjualan, event, dan lain-lain) harus berbicara dengan satu suara, koordinasi merupakan hal yang amat penting untuk menghasilkan citra merek yang kuat dan utuh, serta dapat membuat konsumen melakukan aksi.

\section{METODE PENELITIAN}

Jenis penelitian yang dilakukan yaitu secara kualitatif dengan teknik purposive sampling.Penelitian ini mengenai komunikasi pedagang pasar pekan tradisional di Keude Buloh Blang Ara Kecamatan Kuta Makmur. Penulis memilih hari pekan di Keude Buloh Blang Ara Kecamatan Kuta Makmur tersebut sebagai lokasi penelitian karena hari pekan di Keude Buloh Blang Ara Kecamatan Kuta Makmur sangat ramai pengunjung yang datang dari gampong- gampong dalam wilayah Kecamatan Kuta Makmur. Sudah menjadi tradisi di

Jurnal Jurnalisme Edisi, 1 Volume 10 April 2021 
daerah tersebut, para pengunjung sering menggunakan hari pekan untuk berbelanja, karena pada hari-hari lain mereka sibuk dengan pekerjaan baik di sawah maupun di gunung.

Penelitian kualitatif menurut Sugiyono (2013:59) adalah suatu prosedur penelitian yang menghasilkan data deskriptif berupa pernyataan lisan dari orang-orang dan perilaku yang diamati. Dalam penelitian ini peneliti menggunakan pendekatan kualitatif deskriptif karena peneliti tidak menggunakan rancangan penelitian yang baku dan rancangan penelitian berkembang selama proses penelitian dengan tujuan untuk memahami, mencari makna dan kebenaran tentang komunikasi pedagang pasar pekan tradisional di Keude Buloh Blang Ara Kecamatan Kuta Makmur. Pengumpulan data dilakukan atas dasar prinsip fenomenologis, yaitu dengan memahami secara mendalam gejala atau fenomena yang dihadapi dan peneliti berfungsi sebagai alat pengumpul data sehingga keberadaan peneliti dalam penelitian ini tidak terpisahkan dengan permasalahan yang diteliti.

\section{SUBJEK/INFORMAN PENELITIAN}

Penentuan informan dalam penelitian ini menggunakan teknik purposive sampling. Penggunaan teknik purposive sampling dalam penelitian ini untuk menentukan informaninforman karena tindakannya terlibat langsung dengan permasalahan yang diteliti. Di samping itu peneliti merasa informan yang dipilih paling mengetahui tentang masalah yang akan diteliti. Adapun yang menjadi informan dalam penelitian ini seperti tabel 3.1 berikut:

Tabel 3.1

\section{Informan}

Penelitian

\begin{tabular}{|l|l|l|l|}
\hline No. & Nama & Jabatan & Keterangan \\
\hline 1. & Husaini & Pedagang Kakilima & Informan Kunci \\
2. & Syafruddin & Pedagang Kakilima & Informan Kunci \\
3. & Abdul Hadi & Pedagang Kakilima & Informan Kunci \\
4. & Kartini & Pedagang Kakilima & Informan Kunci \\
5. & Juanda & Pedagang Kakilima & Informan Kunci \\
6. & Fitriani & Pelanggan & Informan Biasa \\
7. & Eka Rahmayanti & Pelanggan & Informan Biasa \\
8. & Safrida & Pelanggan & Informan Biasa \\
9. & Muhammad & Masyarakat Setempat & Informan Tambahan \\
10. & Salmawati & Masyarakat Setempat & Informan tambahan \\
\hline
\end{tabular}

Jurnal Jurnalisme Edisi, 1 Volume 10 April 2021 
Sumber: Olahan Peneliti, 2020

\section{HASIL PENELITIAN DAN PEMBAHASAN}

Pasar tradisional pada hari pekan di Keude Buloh Blang Ara secara administratif terletak di Kecamatan Kuta Makmur yang berada di bagian selatan Kota Lhokseumawe. Kecamatan Kuta Makmur sendiri merupakan salah satu kecamatan dalam wilayah Kabupaten Aceh Utara. Kecamatan Kuta Makmur merupakan ibukota dari Bul;oh Blang Ara, yang mana luas Kecamatan tersebut seluas 151,32 Km /15.132 Ha.

Kemunculan hari pekan sebagai pasar tradisional pada awalnya dimulai dari perdagangan- perdagangan yang berkembang dipinggir-pinggir jalan raya. Para pedagang berkumpul disebuah lokasi, sampai seterusnya berkembang. Mulai dari pedagang makanan dan minuman, peralatan rumah tangga, pakaian dan lain-lain di jual di pasar ini. Sejak saat itulah para pedagang kecil, yang berada di pinggir-pinggir jalan, mulai diatur oleh penguasa dan aparat administratifnya. Pasar tradisional berfungsi sangat penting bagi masyarakat Selain sebagai kekuatan ekonomi, pasar juga berfungsi sebagai perekat hubungan social, sehingga keberlangsungan pasar tradisional tersebut sebagai hari pekan yaitu satu hari dalam satu minggu, yaitu jatuhnya pada hari Sabtu.

Di pasar tradisional nilai-nilai kekeluargaan dibangun dengan hasil interaksi dan komunikasi antar masyarakat. Pada tradisional pula terjadi interaksi antara penjual dan pembeli menemukan eksistensinya dalam proses tawar-menawar antara penjual dan pembeli. Selain itu pola bangunan pasar tradisional sangatlah khas dimana pasar tradisional memiliki tenda-tenda yang memungkinkan interaksi antara penjual dan pembeli berlangsung dengan terbuka. Dengan kata lain, bagi Kecamatan Kuta Makmur, pasar tradisional tidak hanya merupakan penyangga ekonomi namun juga merupakan aset budaya yang harus di lestarikan.

Keberadaan pasar tradisional hari Pekan di Keude Buloh Blang memiliki posisi strategis, karena terletak dijalur transportasi utama yaitu di Keude Buloh Blang Ara yang merupakan pusat perbelanjaan masyarakat. Posisi ini merupakan peluang bagi para pedagang di tradisional hari Pekan di Keude Buloh Blang dan juga para pelaku usaha lain yang ada di pasar tradisional hari pekan di Keude Buloh Blang Ara tersebut untuk ikut menangkap peluang berdagang.

Pedagang pasar hari pekan di Keude Buloh Blang Ara merupakan yang menjual baik itu bahan-bahan pokok kebutuhan sehari-hari (Sayur-sayuran, buah-buahan, kue dan aneka jajan, dan ikan), maupun bahan-bahan kebutuhan tambahan (pakaian dan peralatan dapur). Kebanyakan pedagang yang berjualan di hari pekan di Keude Buloh Blang Ara adalah

Jurnal Jurnalisme Edisi, 1 Volume 10 April 2021 
sebagian besar berjenis kelamin perempuan. Pedagang mulai berjualan biasanya dimulai pukul 9.00 Wib hingga pukul

17.00 Wib. Jumlah pedagang pakaian di pasar tradisional hari pekan di Keude Buloh Blang Ara sebanyak 37 orang yang terdiri dari penjual pakaian anak-anak sebanyak 6 (enam) orang, penjual seragam sekolah 3 (tiga) orang, penjual baju dewasa 7 (tujuh) orang, penjual peralatan dapur sebanyak 2 (dua) orang, penjual aksesoris 2 (dua) orang, penjual mainan anak-anak 4 (empat) orang, dan penjual makanan dan minuman sebanyak 13 (tiga belas) orang.

\section{Komunikasi Pemasaran Pedagang Pasar Pekan Tradisional di Keude Buloh Blang}

\section{Ara Kecamatan Kuta Makmur}

Keberadaan pasar tradisional tentunya sudah mulai terancam dengan adanya pasar modern dan pasar online. Permasalahan lainnya adalah keberadaan pasar tradisional yang kurang jaman untuk melakukan transaksi jual beli, dikarenakan kebanyakan tempat pasar tradisional terlihat kotor dan semerawut, kemudian juga seringkali kualitas barang serta perhitungan harga yang tidak sesuai dengan apa yang diharapkan oleh pembeli, permasalahan ini yang menjadi daya Tarik penelitian ini dikaitkan dengan bagaimana pola komunikasi pedagang dalam menjual dagangannya di pasar tradsional tersebut.

Hal tersebut tentunya memberikan dampak kurang nyaman bagi masyarakat pembeli, serta

masyarakat pada umumnya. Dengan adanya permasalahan tersebut, prospek berjualan berkaitan dengan pendapatan para pedagang tradisional di pasar Tateli, pastinya akan berkurang, berdasarkan permasalahan tersebut. Seperti kita ketahui bersama bahwa pola komunikasi merupakan bentuk-bentuk komunikasi untuk mempengaruhi melalui sinyal atau simbol yang dikirimkan dengan cara mengajak secara bertahap maupun sekaligus, pola komunikasi di sini akan lebih mempunyai arti jauh ketika dikaitkan dengan prinsip-prinsip komunikasi dalam merealisasikan bentuk komunikasi. situasi ini juga terjadi pada interaksi tatap muka antara pedagang dan pembeli, termasuk senyuman serta sapaan ketika individu sebagai pedagang dan individu sebagai pembeli melakukan pembicaraan atau tawar menawar barang dagangan.

Komunikasi pemasaran yang terjadi pada pedagang pasar pekan tradisional di Keude Buloh Blang Ara merupakan suatu aspek yang dipengaruhi oleh tujuan komunikasi yang dilakukan oleh pedagang dan pembeli yang secara sadar maupun tidak mengubah pola komunikasi mereka. Pola komunikasi tidak terlepas dari hal-hal yang mempengaruhinya,

Jurnal Jurnalisme Edisi, 1 Volume 10 April 2021 
seperti pengaruh situasi dalam menentukan perilaku manusia. Menurut Safruddin salah satu pedagang pakaian mengatakan bahwa

"Komunikasi yang dilakukan adalah komunikasi langsung dengan pelanggan terutama dalam tawar menawar harga. Masalah harga yang dipasang hampir sama dengan para pedagang-pedagang yang lain. Di samping menggunakan komikasi langsung, pedagang ini juga menggunakan aplikasi watshaap untuk mempromosi pakaian kepada pelanggan- pelanggannya yang sudah menjadi langganan tetap" (Wawancara, 28 November 2020).

Komunikasi pemasaran antara penjual dengan pembeli terlihat lancar, karena mereka mempunyai tujuan yang sama sehingga komunikasi personal di antara mereka dapat berlangsung dengan mengunakan bahasa formal, bahasa isyarat maupun bahasa-bahasa tubuh. Hasil wawancara dengan Juanda salah satu pedagang pakaian menuturkan bahwa:

Komunikasi langsung antara seorang penjual dan pelanggan individual menggunakan metode promosi selain penjualan personal tatap muka, sebagian besar komunikasi pemasaran langsung dirancang untuk mendapatkan umpan balik segera dari pelanggan (Wawancara, 28 November 2020).

Komunikasi dapat terjadi dalam diri seseorang, antara dua orang, di antara beberapa orang atau banyak orang. Komunikasi mempunyai tujuan tertentu. Artinya komunikasi yang dilakukan sesuai dengan keinginan dan kepentingan para pelakunya. Dalam kegiatan komunikasi sedikitnya harus terdapat tiga komponen, yaitu komunikator sebagai penyebar pesan, pesan yang disampaikan, dan komunikan sebagai penerima pesan. Berhasil tidaknya kegiatan komunikasi sangat tergantung pada ketiga komponen tersebut.

Komunikasi yang terjadi antara pedagang dengan pelanggan dapat terjadi secara langsung dengan cara berhadapan muka atau tidak. Komunikasi seperti ini lebih efektif karena kedua belah pihak saling melancarkan komunikasinya dan dengan feedback keduanya melaksanakan fungsi masing-masing, Hal ini juga terjadi antara pedagang dan pembeli di pasar pekan tradisional di Keude Buloh Blang Ara tersebut, dimana ketika melangsungkan interaksi pastinya keduanya akan terjadi tatap menatap ketika terjadi penawaran harga. Sementara untuk pola komunikasi secara kelompok terjadi juga dalam interaksi antara pedagang dengan rekan pedagangnya, ketika bertanya mengenai harga ataupun stok barang dagangan mereka di pasar tersebut. Komonikasi pemasaran sesama pedagang lebih mengarah kepada penetapan harga pakaian agar tidak terjadi tumpang tindih antara pedagang yang satu dengan lainnya pada produk yang sama. Safrida, salah satu pelanggan dalam wawancaranya dengan penulis mengatakan bahwa:

"Komunikasi pemasaran yang terjadi yaitu komunikasi secara langsung seperti

Jurnal Jurnalisme Edisi, 1 Volume 10 April 2021 
dalam tawar menawar harga pakaian, menunjukkan produk-produk dan modelmodel pakaian, penjual menyampaikan kualitas pakaian dan lain sebagainya. Ada juga beberapa konsumen yang sudah menjadi langganan tetap, para penjual menggunakan whatshapp dan instagram untuk menginformasikan pakaian dengan model-model terbaru sebagai bentuk promosi produk yang dijualnya" (Wawancara, 28 November 2020).

Komunikasi pemasaran yang dilakukan oleh pedagang pada pasar pekan tradisional di Keude Buloh Blang Ara adalah melalui promosi. Promosi yang dipilih adalah whatshapp dan instagram dengan tujuan meberikan informasi pada calon konsumen, mengubah sikap dan keyakinan atau perasaan konsumen, menstimulasi agar pelanggan melakukan pembelian, mempengaruhi dan meyakinkan pada konsumen produk yang berkualitas. Penerapan komunikasi pemasaran disini sama halnya dengan promosi. Promosi yaitu kegiatan terpenting, yang berperan aktif dalam memperkenalkan, memberitahukan dan mengingatkan kembali manfaat suatu produk agar mendorong konsumen untuk membeli produk yang dipromosikan tersebut.

Hasil wawancara dengan Kartini salah seorang pedagang kaki lima di pasar pekan tradisional di Keude Buloh Blang Ara, yaitu sebagai berikut:

"Komunikasi yang terjadi antara pedagang dengan pembeli, adalah dengan konsep tatap muka, dimulai oleh pedagang dengan menawarkan jualan secara langsung kepada pembeli, sarana komunikasi pedagang adalah mulut dan suara mereka, untuk menarik perhatian pembeli disaat datang di pasar, mulut yang paling ribut serta suara yang paling keras dari seorang penjual akan sangat memungkinkan menarik perhatian pembeli untuk datang di lapak penjual tersebut" (Wawancara, 21 November 2020).

Dalam hal menyampaikan pesan-pesan pemasaran, bahasa non formal yang digunakan pedagang bisa dikatakan sebagai komunikasi dalam keseharian mereka khususnya dalam bertransaksi jual beli baik itu dilakukan secara langsung maupun melalui pesan.

\section{Kendala-Kendala Dalam Komunikasi Pemasaran pada Hari Pekan di Keude Buloh Blang Ara Kecamatan Kuta Makmur}

Daya saing dari pasar tradisional tidak begitu mudah terkalahkan, tidak sedikit masyarakat yang masih berbelanja di pasar tradisional. Hal ini diyakini bahwa ada nilai tambah khusus yang dimiliki oleh para pedagang pasar tradisional seperti terjadi interaksi pedagang kepada pelanggannya dan memberikan langsung apa yang pelanggan butuhkan berbeda seperti pasar modern yang memiliki sistem dimana pembeli mengambil barang

Jurnal Jurnalisme Edisi, 1 Volume 10 April 2021 
sendiri yang dibutuhkan. Namun, sesama pedagang maupun pembeli mengalami beberapa kendala dalam komunikasi pemasaran.

Komunikasi pemasaran menjadi suatu hal yang teramat penting dalam dunia bisnis. Suatu kegiatan bisnis memerlukan komunikasi yang baik agar dapat berjalan lancar dan sukses. Setiap pebisnis atau pelaku bisnis tentu sudah pasti menginginkan adanya komunikasi bisnis yang baik dalam usahanya. Namun terkadang hal tersebut harus berhadapan dengan berbagai hambatan yang dimungkinkan terjadi dalam setiap komunikasi pemasaran.

Kendala-kendala dalam komunikasi pemasaran pada hari pekan di Keude Buloh Blang Ara Kecamatan Kuta Makmur, Menurut Safruddin salah satu pedagang pakaian mengatakan bahwa:

Kendala yang dihadapi yaitu para pedagang disini mempunyai barang yang berkualitas dan memliki barang yang lengkap. Maka dari itu, setiap pedagang harus berusaha menyediakan barang yang berkualitas dan juga lengkap karena keinginan konsumen beraneka ragam. Disamping itu kendala yang dihadapi banyak bisnis online yang berkembang pesat sehingga pedagang pakaian harus bersaing dengan produk-produk online (Wawancara, 21 November 2020).

Komunikasi pemasaran pada hari pekan di Keude Buloh Blang Ara Kecamatan Kuta Makmur harus berjalan dengan efektif, gunanya untuk mengantisipasi persaingan dengan pedagang lainnya. Oleh karena itu para pedagang tetap meningkatkan kemampuan komunikasinya dengan cara ramah dan sopan kepada pembeli, hal ini tentunya dapat menarik perhatian pembeli untuk memutuskan membeli barang tersebut. Juanda salah satu pedagang pakaian menuturkan bahwa:

Salah satu kendala yang dihadapi dalam komunikasi pemasaran yaitu hambatan personal yang merupakan hambatan yang terjadi pada peserta pelanggan yang mana pelanggan hanya menanyakan dan melihat-lihat saja bukan untuk membeli. Disamping itu, pedagang harus memahami perbedaan dalam hal nilai-nilai, kepercayaan, dan sikap yang dipegang oleh pembeli. (Wawancara, 21 November 2020).

Adanya kebutuhan akan barang oleh pembeli memungkinkan pembeli untuk datang ke pasar dan melakukan pembelian pada pedagang pasar, hal ini tentunya akan terjadi situasi hubungan interpersonal, melalui percakapan, proses tawar menawar dan pada akhirnya dapat terjadi deal atau persetujuan harga sehingga terjadi keberhasilan transaksi dagang. Namun ada sebagian masyarakat yang datang hanya untuk melihat-lihat saja tanpa memutuskan untuk membeli.

Jurnal Jurnalisme Edisi, 1 Volume 10 April 2021 


\section{KESIMPULAN}

Berdasarkan hasil penelitian mengenai komunikasi pedagang pasar tradisional pada hari pekan di Keude Buloh Blang Ara Kecamatan Kuta Makmur dapat disimpulkan bahwa :

1. Komunikasi pemasaran pedagang pasar pekan tradisional di Keude Buloh Blang Ara Kecamatan Kuta Makmur yaitu penjualan langsung melalui tatap muka dengan pelanggan maupun menggunakan aplikasi watshaap terutama untuk promosi penjualan, mengikat hubungan dengan pelanggan terutama pelanggan-pelanggan baru. Dalam hal ini, penjual berupaya untuk membantu atau membujuk calon pembeli untuk membeli produk yang ditawarkan. Komunikasi yang terjadi antara pedagang dengan pembeli, adalah dengan konsep tatap muka, dimulai oleh pedagang dengan menawarkan jualan secara langsung kepada pembeli.

2. Kendala-kendala dalam komunikasi pemasaran pada hari pekan di Keude Buloh Blang Ara Kecamatan Kuta Makmur yaitu; setiap pedagang harus berusaha menyediakan barang yang berkualitas dan juga lengkap karena keinginan konsumen beraneka ragam, hambatan personal yang mana pelanggan hanya menanyakan dan melihat-lihat saja bukan untuk membeli, tingkat kenyaman dalam berkomunikasi karena suara bising, produk harus dikemas sedemikian rupa sebagai media penyampai pesan dari pedagang kepada calon pembeli sehingga muncul minat pelanggan untuk membeli, dan banyak bisnis online yang berkembang pesat sehingga pedagang pakaian harus bersaing dengan produk-produk online.

Jurnal Jurnalisme Edisi, 1 Volume 10 April 2021 


\section{DAFTAR PUSTAKA}

Akhmad, 2007. Ekonomi Islam, Raja Grafindo Persada, Jakarta.

Djamarah, Bahri Syaiful, 2004. Pola Komunikasi Orang Tua dan Anak Dalam Keluarga. Reneka Cipta, Jakarta.

Effendy, Onong Uchyana, 2003. Ilmu Komunikasi, Teori dan Praktek. Remaja Rosda Karya, Bandung.

Fajar, Marhaeni. 2009. Ilmu Komunikasi dan Praktik. Graha Ilmu, Jakarta. Hariyono, Paulus, 2007. Sosiologi Kota Untuk Arsitek. Bumi Aksara, Jakarta. Kasmir, 2016, Kewirausahaan, Raja Grafindo Persada, Jakarta.

Kennedy, dan Soemanagara, 2006. Strategi Marketing Communication: Konsep Strategis dan Terapan, Alfabeta : Bandung.

Kotler, Philip. 2005. Manajemen Pemasaran. Jilid 1 dan 2. Indeks, Jakarta .

Kensil, C.S.T. dan Christine S.T. Kansil, 2008. Pokok-pokok Pengetahuan Hukum Dagang Indonesia, Sinar Grafika, Jakarta.

Kotler, Philip dan A.B Susanto, 2009. Manajemen pemasaran di Indonesia Analisis, perencanaan, Implementasi dan pengendalian, Salemba Empat, Jakarta.

Moleong, Lexy, J., 2014. Metodologi Penelitian Kualitatif, Remaja Rosdakarya, Bandung.

Zainal Mukarom, Zainal, 2015. Manajemen Public Relation Paduan Efektif Pengelolaan Hubungan Masyarakat", Pustaka Setia, Bandung.

Mulyana, Deddy, 2013. Ilmu Komunikasi Suatu Pengantar. Remaja Rosdakarya, Bandung.

Pareno, S. A. 2002. Kuliah Komunikasi. Papyrus, Surabaya.

Purwanto, Djoko, 2011. Komunikasi Bisnis. Erlangga Jakarta.

Pusat Bahasa Departemen Pendidikan Nasional, 2001. Kamus Besar Bahasa Indonesia. Balai Pustaka, Jakarta.

Riyanto, Agus, 2011, Buku Ajar Metodologi Penelitian, EGC, Jakarta.

Shimp, Terence, 2007. Periklanan Promosi ( Aspek Tambahan Komunikasi Pemasaran Terpadu)". Jilid I, edisi Terjemahan, Erlangga, Jakarta.

Simamora Henry, 2000. Manajemen Pemasaran internasional. Salemba Empat, Jakarta.

Sudarmo, Indriyo Gito, 2014. Manajemen Pemasaran, BFFE, Yogyakarta. 
Soejanto, A., 2005. Psikologi Perkembangan. Rineka Cipta, Jakarta.

Sugiharsono, dkk., 2000. Ekonomi. Grafindo Media Pratama, Jakarta.

Sugiyono, 2013. Metode Penelitian Kuantitatif, Kualitatif, dan $R \& D$. Cet XIV. Alfabeta, Bandung.

Suyatno, Bagong dan Kanarji, 2005. Kemiskinan dan Kesenjangan Sosial: Ketika Pembangunan Tak Berpihak Pada rakyat Miskin. Airlangga University Press, Surabaya.

Swasta, Basu dan Irawan, 2004, Manajemen Pemasaran Modern, Liberty, Yogyakarta.

Tjiptono, Fandy, 2008. Strategi Pemasaran. Edisi 3. Andi, Yogyakarta.

Widjaja, A.W., 2002. Komunikasi dan Hubungan Masyarakat. Bumi Aksara, Jakarta.

Wursanto, 2005. Dasar-Dasar Ilmu Komunikasi. Andi Offset, Yogyakarta. 
Azeharie, Suzy, 2015, Pola Komunikasi Antara Pedagang dan Pembeli di Desa Pare, Kampung Inggris Kediri,Jurnal Komunikasi , Vol. 7, No. 2, ISSN 2085-1979

Lengkey, Christy, 2019, Pola Komunikasi Pedagang Tradisional Dalam Menjual Bahan Dagangan di Pasar Tateli Kecamatan Mandolang, Jurnal Komunikasi, Vol. 1, No.1.

Masito, Eis Al, 2013, Upaya Menjaga Eksistensi Pasar Tradisional: Studi Revitalisasi Pasar Piyungan Bantul, Jurnal PMI, Vol. 10, No. 2.

Suprapto, H., dkk., 2011, Perilaku Komunikasi Pecandu Game Online dengan Menggunakan Game Online, E-Jurnal Universitas Padjajaran, Vol. 1, No.1.

Sutarso, Joko, 2017, Pola Komunikasi Pedagang dan Pembeli di Pasar Tradisional: Perspektif Jender di Pasar Sidodadi Kleco Surakarta.

Ulyati, Nur Faeni, 2015, Strategi Pemasaran Pedagang Pasar Tradisional Dalam Perspektif Ekonomi Islam (Studi Kasus di Pasar Lebaksiu-Tegal). Skripsi: Fakultas Ekonomi dan Bisnis Islam Universitas Islam Negeri Walisongo Semarang. 